City University of New York (CUNY)

CUNY Academic Works

2003

\title{
The Race for Globalization: Modernity, Resistance and the Unspeakable in Three African Francophone Texts
}

Francesca Sautman

CUNY Hunter College and CUNY Graduate Center

\section{How does access to this work benefit you? Let us know!}

Follow this and additional works at: http://academicworks.cuny.edu/gc_pubs

Part of the African Languages and Societies Commons, French and Francophone Literature Commons, and the Race, Ethnicity and Post-Colonial Studies Commons

\section{Recommended Citation}

Sautman, Francesca. “The Race for Globalization: Modernity, Resistance and the Unspeakable in Three African Francophone Texts.” French and Francophone/Yale French Studies 103 (May 2003): 106-22.

This Article is brought to you by CUNY Academic Works. It has been accepted for inclusion in Publications and Research by an authorized administrator of CUNY Academic Works. For more information, please contact AcademicWorks@gc.cuny.edu. 


\section{The Race for Globalization: Modernity, Resistance, and the Unspeakable in Three African Francophone Texts}

The "global village" that media pundits and politicians evoke as general currency might well be visualized, in this onset of the twenty-first century, as a village beset by fires, riot, and rampage, where in the stealth of the night one is massacred by neighbors who worship or look differently, or escapes into exile, where hunger reigns unopposed. The paradox of the term poorly conceals the untold violence that the violence of rhetoric seeks to erase. Yet, contemporary African Francophone ${ }^{1}$ texts have been tearing off this mask for decades, locating themselves less often in idyllic villages, and more frequently, on the cable lines of suffering between dying villages and indigent cities. In the literature of the 1980s, the focus of this essay, the "village" is already deeply affected by "global economies," but it is hardly a place of intersections, exchange, and communication. Rather, it might be the decaying Congolese village bordered by a cemetery in Tchichelle's "Ilotes et Martyrs" ${ }^{2}$; or the Malian village in Mande Alpha Diarra's Sahel! sanglante sécheresse, ${ }^{3}$ with its hallucinatory hunger under a brutal regime that steals international aid. ${ }^{4}$ Or it could be overcome by famine, banditry, and repression in Moussa Konaté's Le prix de l'âme. ${ }^{5}$ Or again, it might be perched on sterile Malagasy laterite soil, in Michèle Rakotoson's Le bain des reliques. ${ }^{6}$ In the war of metaphors, the "grand village afri-

1. See my "Hip-Hop/scotch: Sounding Francophone in French and United States Cultures," France/USA: The Culture Wars, Yale French Studies 100 (2001): 119-45.

2. Tchichelle Tchivéla, "Ilotes et martyrs," in Longue est la nuit (Paris: Hatier, 1980), 82-104; 91.

3. Mande Alpha Diarra, Sahel! Sanglante sécheresse (Paris: Présence africaine, 1981).

4. See other texts of the 1980s on hunger: Modibo Sounkalo Keita's L'archer bassari (Paris: Karthala, 1984) and Cheikh C. Sow's Cycle de sécheresse (Paris: Hatier, 1983)

5. Moussa Konaté, Le prix de l'âme (Paris: Présence africaine, 1981).

6. Michèle Rakotoson, Le bain des reliques, (Paris: Karthala, 1988).

YFS 103, French and Francophone, ed. Farid Laroussi and Christopher L. Miller, (C) 2003 by Yale University. 
cain" evoked by Sylvain Bemba ${ }^{7}$ stands at the confluence of the dying village and of the "global village's" pretensions to equitably fuse large and small, rural and urban, local and transnational, indigenous and foreign. And, with millions of Africans on the brink of starvation, politically engaged African writers transform the art of writing as they testify against hunger, political repression, corruption, neocolonialism, genocide, poverty, the condition of women, AIDS, exile, and daily hardship. ${ }^{8}$ Their writing is thus an act of resistance against the blandness of postcolonial representations in which all these conditions appear as mere historical accidents. From the 1970 s to the present, writers the world over have shared a language of denunciation aimed at neocolonialist and imperialist controls of their cultures and economies. In African texts of the 1980s, that language is noticeably the vector of a descriptive violence that becomes transgressive in its very excess.

Postcolonial theory has deeply modified textual interpretation, questioning the mechanisms of modernity in relation to the "post" world. The reading of Francophone texts must also account for globalization by reaching beyond the postcolonial and incorporating the echoes of resistance to the new world order. The riots of the 1990s in West Africa against the devaluation of the CFA franc, or the placards and gasoline bombs hurled in the streets of Europe and North America at world leaders deciding under heavy protection the fate of entire populations, shadow contemporary, politically engaged literature. African Francophone texts are not transparent palimpsests of the cultures producing them, obliging mirrors of a cultural difference, translated, made palatable and "user friendly" for Western readers. These texts are often painful interrogations of the meaning of modernity-and of postmodernity as well. While seamless accounts of "tradition," colonialism, and postindependence society produce an exonerated version of modernity and reinscribe it into a grand narrative of progress, African Francophone writers make audible and intelligible the sorrow, the clamor, the anger inherent in the competing realities of a continent embattled in what its rulers have anointed the "global world."

7. Sylvain Bemba, Conversations congolaises, ed. Alain Brezault and Gérard Clavreuil (Paris: L'Harmattan, 1989), 33.

8. For a panorama of African Francophone literature during the 1980s, see Ambrose Kom, Dictionnaire des oeuvres littéraires de langue française en Afrique au Sud du Sahara, II 1979-1989 (San Francisco: International Scholars Publications, 1996); and Pius Ngandu Nkashama, Dictionnaire des oeuvres littéraires africaines de langue française (Ivry: Éditions Nouvelles du Sud, 1994). 
I shall thus discuss three novels, all published in 1988, that are part of a resistant trend in African Francophone writing that emerged as a "new wave" in the 1970s and flourished in the 1980s. ${ }^{9}$ These works implode the violence of representation through the violence of enunciation. In them, discursive racial and colonial subjugation is seized and turned around as a weapon aimed at modernist and postmodern complacency. Such texts "write back" to critique and reinterpret Western power structures and to reject the allegedly all-knowing Western gaze. ${ }^{10}$

Michèle Rakotoson's Le bain des reliques, Doumbi-Facoly's Certificat de contrôle anti-sida, ${ }^{11}$ and Yodi Karoné's Les beaux gosses ${ }^{12}$ were published at a time when the African continent as a whole was reeling from the effects of the world economic recession of the $1980 \mathrm{~s}$ and when the AIDS pandemic had marked transnational consciousness. ${ }^{13}$ Rakotoson evokes famine and the political repression in Madagascar that had just resulted in the deaths of student demonstrators; ${ }^{14}$ Karoné addresses urban poverty, violence, and ghettoization in the Ivory Coast in the aftermath of the early 1980 s economic crisis. ${ }^{15}$ Doumbi-Facoly dares to denounce the phobias elicited by HIV-AIDS.

9. See Madeleine Borgomano, "Linguistic and Cultural Heterogeneity and the Novel in Francophone Africa," in African Francophone Writing: A Critical Introduction, ed. Laila Ibnlfassi and Nicki Hitchcott (Oxford, Washington: Berg, 1996), 125-138. Jonathan Ngate, Francophone African Fiction: Reading a Literary Tradition (Trenton, NJ: Africa World Press, 1988), 32-37. Also Pius Ngandu Nkashama Écritures et discours littéraires: Études sur le roman africain (Paris: L'Harmattan, 1989), 242-51.

10. Yet, for those who control discourse and the world, says Glissant, it is impossible to give up its "false transparency," to accept merely being in the world, and entering its "penetrable opacity." Édouard Glissant. Poétique de la relation. Poétique III (Paris: Gallimard, 1990), 128-29.

11. Doumbi-Facoly, Certificat de contrôle anti-sida (Paris: Publisud, 1988).

12. Yodi Karoné, Les beaux gosses (Paris: Publisud, 1988). All translations from these three works are my own.

13. See Walter O. Oyugi et al., eds., Democratic Theory and Practice in Africa (Portsmouth, NH: Heinemann; London: James Currey, 1988); and Dov Ronen, ed., Democracy and Pluralism in Africa (Boulder, Co: Lynne Rienner Publishers, 1986).

14. See Ferdinand Deleris, "De la charte de la Révolution socialiste malagasy aux assises de la francophonie," Géopolitique africaine (GA), Le scandale malgache (1985): 63-86; "Lettre pastorale des évêques de Madagascar pour le carême 1985," Ibid, 87-94. NA, "Bras de fer à Madagascar," GA (October 1987): 91-106. Rakotoson, "Instaurer une véritable politique culturelle," Madagascar: Refondation et développement. Quels enjeux pour les années 2000?, ed. Patrick Rajoelina (Paris, Montréal: L'Harmattan, 1998), 133-36.

15. See Pascal Koffi Teya, Côte d'Ivoire. Le roi est nu (Paris: L'Harmattan, 1985). For Pro-Western views, see Jean-Marc Kalflèche, "Côte d'Ivoire. Le congrès de la consolida- 
What connects these works of the late 1980s to globalization? Jo Anne Pemberton suggests that references to the "globe" were common around World War II in arguments for world order, but the term did not become common until after 1960, "referring to a process of worldwide integration" used at the outset "to refer to long-term historical developments as well as a wide range of phenomena," and seen by its proponents as "also a bearer of the new." 16 In 1988, few works in the social sciences or in history evoked the term globalization openly, whereas, since 2000 , hundreds of such titles are published in a year. Likewise, in literature, direct responses to globalization are more evident in works of the year 2000 such as Kourouma's Allah n'est pas obligé, which denounces the horrors of war in Liberia and Sierra Leone, international indifference, and the destructive intervention of the ECOMOG forces. Or Mongo Beti's Branle-bas en blanc et noir, which announces the ethnic clashes of the Ivory Coast and Cameroon, between North and South, Muslim and Christian/animist. Yet, writing from the late eighties does embody-literally, since it inscribes suffering, abject bodies in texts-a poetics of denunciation and resistance to the "global world." This is an important moment in African Francophone literature: the violence of representation reappropriated by former colonial subjects in an act of literary agency complicates postindependence denunciations of homegrown dictatorships and of foreign intervention, often within a Marxist framework. In the 1980s, these texts already acknowledged that many aspects of today's world are global, while formulating a resistant discourse on mass poverty and war that is not ascribed to the actions of a single Western power, but to the global West, for which the present USA often acts as a "stand-in." This poetics, which often makes the body central to its representational strategies, leads me to theorize resistance at least in part as giving voice to the unspeakable.

Globalization will thus be treated as a phenomenon overlapping with but distinct from imperialism, whose main characteristics are the interconnectedness of media, culture, and police and information services; massive transnational conglomerates and free trade operating to their advantage; international intervention in local conflicts; the ex-

tion," GA (March 1986): 113-120, and Yves Catalans, "Côte d'Ivoire. La continuité a triomphé de la crise," Ibid., 121-132.

16. Jo Anne Pemberton, Global Metaphors: Modernity and the Quest for one World (London, Sterling Va.: Pluto Press, 2001), 154. 
pansion of racial boundaries, simultaneous with increased ethnic warfare; the impact of pandemics such as AIDS on international and national policy, linked in part to the numbers infected but also to the cultural implications of its means of transmission. These elements are paralleled by world-wide tensions around uniformization of cultural products and social custom, and linguistic dominance, countered by renewed fervor for national and local languages, and the careful manipulation of tradition. ${ }^{17}$ Occupation of space, the role of locality and place, as Saskia Sassen has remarked, are crucial correctives to globalization, allowing agency to marginalized peoples. ${ }^{18}$

The "global" world also produces a transnational postmodern text, often written in exile, or uprooted, or even eschewing all roots. ${ }^{19}$ Thus, Rakotoson's text, written in France, addresses ethnic clashes and historical scars in Madagascar. Karoné, a Cameroonian, chose to write about the Ivory Coast and its quasi-mythical city, Abidjan, filled with immigrants from Burkina-Faso, Ghana, and the Sahel. Finally, DoumbiFacoly, a Malian living in Senegal, placed his novel of AIDS discrimination in a recognizable France and left the African nation at stake unnamed. All three novels also adopt traits of the mystery novel, a genre given to spatial uncertainties and identity breakdowns. While the characters are not detectives, they struggle desperately to find out the truth before it kills them, possibly the very truth that will kill them: such is the case of Ranja, Kairuane, and the mother-daughter couple in Certificat. Thus both nation and truth are uprooted and shifted into dangerous waters, where textuality gives substance to fluid, unstable realities.

Such texts also exemplify a current in African Francophone writing of the last decades that makes the unspeakable readable. This refers not merely to something that is impossible or extremely difficult to "say," but further, to utter; it is connected to voice, not merely to communication. In the word "unspeakable," in English, there is also a subjective notion of that which cannot/should not be spoken because it is indecent, scandalous, morally repugnant, as in "unspeakable acts." It

17. See Célestin Monga, Anthropologie de la colère: Société civile et démocratie en Afrique (Paris: L'Harmattan, 1994), 30-50.

18. Saskia Sassen, Globalization and its Discontents (New York: The New Press, 1998), introduction, esp. xxi.

19. See Mongo Beti, "L'exil après l'exil?" Peuples noirs, peuples africains [PNPA] 14.80 (March-April 1991): 110-25. Azadé Seyhan, Writing Outside the Nation (Princeton and Oxford: Princeton University Press, 2001). 
inscribes violence in the word because it forces to speak that which should remain silenced, against one's wishes or against censorship. Unspeakable reaches beyond conceptualization, grapples with making known what is already there but hidden, and seeks spaces of enunciation unencumbered by previous modes of discourse.

The power of neocolonialism and imperialism can thus only be matched by the textual resistance of voicing the "unspeakable." Such texts effectively displace the remnants of discourse bequeathed by modernity by the use of enunciatory resistance: gruesome acts of violence and relentless economic oppression are not merely described as elicited by African actors, but are shown in a context where nonAfricans operate freely as communities or as tentacular economic powers. What Homi Bhabha calls the "disjunctive temporalities of modernity," ${ }^{20}$ are expressed in the narrative mode of disarray (as in Tchichelle's 1980 short stories, and in Karoné's and Doumbi-Facoly's breathless narrative style) and by a fierce identification of lack, inequity, and violence. Speaking the unspeakable reflects Bhabha's "locus and locution of cultures caught in the transitional and disjunctive temporalities of modernity." 21

The novels I discuss here are representative of a wide current in African writing that refuses to quietly acquiesce to a "postcolonial condition." For Guy Ossito Midiohouan, postindependence writing, especially since 1970, has yielded a specifically Black African novel, with "a systematic strategy of transgression... [and] a rebel imagination." 22 What some political analysts have termed "patrimonial authoritarianism" in all the regimes of Francophone Africa that came to power in the 1970s, has been made possible, according to Achille Mbembe, by an entire culture of the "postcolony." This postcolony is at once a political regime and a culture, "to some extent deprived of references to face modernity and delivered to . . . sex, the belly, and the sacred. ${ }^{23}$ In

20. Homi K. Bhabha, The Location of Culture, (New York and London: Routledge, 1994), 250-51.

21. The notion of the unspeakable is useful as well in reading other novels of the eighties. See Ibrahima Ly's Toiles d'araignées, (Paris: L'Harmattan, 1982), a terrifying account of incarceration in Beleya prison. In La retraite anticipée du Guide Suprême (Paris: L'Harmattan, 1989), Doumbi-Facoly evokes the torture of political prisoners as acts that, because they are too horrific to witness, must be reconstituted by sound and remain as visible traces in the bruising and cutting of lips (160-67).

22. Guy Ossito Midiohouan, L'utopie négative d'Alioum Fantouré. Essai sur le Cercle des Tropiques (Paris: Silex, 1984), 12-16.

23. Alain Ricard, "La libération de la parole en Afrique francophone 1989-1992," 
effect, Rakotoson, Karone, and Doumbi-Facoly undermine and distance the very notion of postcolony through three complex "denunciatory" novels that are written against an odious, at times occult, encroaching global reality. Yet, none of these three novels blandly embraces "tradition" as an antidote to the brutalities of modernity; rather, echoing V. Y. Mudimbe's rejection of modernity and tradition as a suspect dichotomy, ${ }^{24}$ they question global agendas and the deep scarring left by modernity, while taking a critical look at "tradition's" changing and multifarious role.

\section{LE BAIN DE RELIQUES}

In Rakotoson's novel, a journalist from the city is invited to film an ancient ceremony, a sacred ritual of Malagasy royalty in a forlorn region, the Mid-West. The motives of his employer and the politicians who organize the filming are suspect, and he discovers fragments of an oppressive reality filled with starvation and political massacres. But he cannot complete his work, for he is killed in mysterious conditions, after a tryst with the local warlord's woman.

Bain strongly bears out Homi Bhabha's notion of "distanciating." Underlining Fanon's role in opposition to an ontology of Black man's "belatedness," Bhabha advocates writing that does not merely contradict "the metaphysical idea of progress or racism or rationality," but "distanciates them," "making them uncanny by displacing them in a number of culturally contradictory and discursively estranged locations" (36-37). As we shall see, this process is at work in Bain. Further, if modernity is, as Appadurai has suggested, inseparable from a dominant narrative of historical origin (2-3) based on racial hierarchies, it reveals its own vulnerability. In an uncompromising interrogation of the defining historical moment of independence, African Francophone writers such as Rakotoson unsettle the continuities and hierarchies of modernity's complacent colonial world; they rescue submerged blocks of history, of discourse, of memory. In Bain, a voice rises through the narrative collusion of oral and written, fragile but undaunted. The past - the ancestral ceremony of royal relics - is inscribed in the very first pages, the prologue, with the repetition of the formula "once upon

Afriques imaginaires. Regards réciproques et discours littéraires $17^{e}-20^{e}$, ed. Anny Wynchank and Philippe-Joseph Salazar (Paris: L'Harmattan, 1995), 281-95; 293.

24. V. I Mudimbe, The Invention of Africa (Bloomington and Indianapolis: Indiana University Press, 1988), 189, 197. 
a time there was the ceremony" (7-8), an incantation or prescriptive enunciation against forgetting, against the quiet acquiescence to the global culture that will follow in the next pages, which describe the city. That past is then distanced to another region, with a strange, barren landscape, another set of geopolitical contours, creating an almost "ethnological" inserting of the ancestral ritual that then turns inward, against its observers, although they are Malagasy as well. Finally, it is the strangeness of film in a place so isolated and bereft of basic survival needs, its anachronic disjuncture with both the ceremony and the place itself, combined with the irrelevance of "rationality" in the ceremonial proceedings, that effect that distancing.

Ethnic tensions within one nation are an important sub-theme of Le bain des reliques. All the protagonists are Malagasy, but there are strong differences between the people of the coasts and those of the high plateaus, as well as underlying Black/White dichotomies. The street children and beggars are called andevo (son of a slave), "the woe of those born a little darker, a little curlier" (21). Government massacres of villagers, with hundreds, sometimes thousands, of bodies piling up and rotting in the sun cement a deep estrangement between ethnic groups and city versus rural regions. The villagers refer to the film crew members from the city as "from the white men's land," "foreigner, white $\operatorname{man}^{\prime \prime}(7,51)$. City dwellers are considered richer, more modern, and thus in collusion with oligarchy and imperialism; the villagers are poorer but somehow nobler, less tainted (73-83). Thus the hero at once disdains their ways (24) and feels inferior with respect to caste and race $(51,53,56)$; he marvels that "he, the man from the high plateaus, the mavo ranjo, the man with the sallow calves, the pale man of the sunless hills, the man from the hated ethnic group, would be allowed to film, tell, record, preserve" (29).

In Bain, Antananarivo is a dreary, indigent city inhabited by desperate bands of abandoned children who live off theft and are kept in line through mutilations by the militia and their own street hierarchy $(18-20,24)$. Urban banditry had become a major social question in Madagascar in the 1980s, and it had ethnic and racial dimensions. In contrast to the deprivation experienced by the many, the global world leaves its traces in the form of money and consumer goods-French pastry shops, US soft drinks, and the World Bank. Such textual markers reflect disillusion with Western economic promises, resentment of dependency, anxiety at cultural homogenization, and resistance to the role of US-controlled financial institutions in African economies. 


\section{LES BEAUX GOSSES}

Kairuane's real father is a marginalized dancer, and his mother is a hasbeen musician and a drug addict. However, he thinks he is the son of a powerful gangster, who raised him in luxury, after inflicting crippling injuries on the dancer in a fight. When the gangster is murdered, Kairuane falls into the spiraling heel of economic deprivation, petty crime, and deception. He is finally executed by his acolytes after murdering his real father.

Like Bain, Les beaux gosses complicates ethnic and national scripts, here through the presence of the rich Lebanese community, culturally different but invested with a considerable amount of power, who commandeer part of the underworld and work in collusion with local powers. Implicit in the novel is the question of citizenship and nationality, central in later Ivory Coast politics: indeed, "ivoirité" provoked riots with the results of the March 2002 elections.

Abidjan, the setting of Les beaux gosses, is an international site, teeming with poverty and crime, whose inhabitants develop strategies of economic and cultural survival similar to those of modern American ghettoes and French urban zones. ${ }^{25}$ And "Les beaux gosses" ["beautiful kids"] is not, as one might surmise, a nickname for delinquent youth, but a sumptuous villa, surrounded by lavish gardens, and situated high up on a hill, yet still close to Treichtown, the slum. The villa, even abandoned, and the urban topography-hill, lagoon, slums, coastline-are the locus of fantasies and hopes, and underdevelopment is the hidden face of a blatant overdevelopment characterized by brash consumerism. In the novel, urban crime becomes a site of potential resistance to the cynical efficiency of official power, incarnated here by the coalition of the Ivorian political class and the rich Lebanese. References to the Black American city are very ambiguous: the fresco depicting "Harlem the negress" is painted on the jail wall with shoe polish, paint, chalk, and even blood by the professional killer Mobio. It features, over Harlem, the severed hand of the Statue of Liberty, an Arabian stallion prancing in front of a limousine draped in the US flag, a boxer watch-

25. The stark film Bronx-Barbès (2000) depicts street youth in Abidjan. Dir. Eliane de Latour, scr. Emmanuel Bourdieu and Eliane de Latour. On Abidjan: Alain Bonnaissieux, L'autre Abidjan. Chronique d' un quartier oublié (Abidjan: Inades; Paris: Karthla, 1987); Philippe Haeringer, Abidjan au coin de la rue. Éléments de la vie citadine dans la métropole ivoirienne (Paris: Cahiers ORSTOM, Série sciences humaines, 1983, 19/4). 
ing Marilyn Monroe falling down the Empire State Building, and a black child who has placed his head on his skateboard to listen to a sermon by the Reverend Jesse Jackson, crucified on a cement cross (32). Mobio claims to be an "American," rotting by mistake in this Ivorian jail: he subscribes to a revisionist version of slavery, admonishing his pupil to not believe "all that nonsense they tell about slaves." In his own counternarrative, women and ancient African history are stepping stones to male agency: his ancestor, he claims, sold his three wives to gain passage on the boat, then impregnated a "Malinke lady" on-board and "reached the promised land" together with her (39). Mobio, paid to enforce the underworld criminal order of the Lebanese businessmen, dreams of going to the USA, but to kill people for more money. In his words, the American dream has become the American nightmare. Americans, he adds, love death "with napalm, chain saws, electricity," because of the "Indians, the Secession War, the Mafia, Vietnam ..." (41).

The "reverse rooting" of African Francophone texts in AfricanAmerican literature in diasporic and transnational counter-roots usually links unsettling notions of "race" to African postcolonial identities and disjunctive interventions in the "violence of representation." But, in the postmodern, postcolonial context the mythical nature of America/the USA/New York bequeathed by modernity has shifted dramatically, ${ }^{26}$ as it does in Karoné's novel: Black America has lost some of its salvific value and become part of America the globalizer.

Karoné's novel also underscores the tensions between hybridity and globalization. Half African, Julie Madola is a talented musician, but her musical genius and the musical culture she represents are devalued, even silenced. When she and the dancer try a comeback, Julie's previous fame draws a crowd that does not, however, understand her music. She refuses to play the bland cocktail lounge jazz they are accustomed to, turns her back on the audience, and plays discordant, disdainful notes on her sax, which becomes her true voice and mouth, freed and regenerated from its previous confinement to sexual subjection and humiliation under the gangster's rule. Only her fellow musicians, including an American from the Bronx, understand the despair and re-

26. See Guy Rossatanga-Rignault, "Vieilles lunes et nouveaux empires. Un regard africain sur la France et les Etats-Unis," Afrique, la fin du Bas Empire, LiMes. Revue française de géopolitique 3 (1997): 67-79. 
bellion she is sounding to the very end of her music. The fiasco is a reflection on the tyranny of global culture. Julie's Afro-Caribbean jazz is unpalatable to these West African consumers, who, like the gangster, do not see jazz "as they do in America as a liberating music" (58). In contrast, "Summertime," played by popular demand, encodes racial and global hierarchies. For Julie and the musicians, it has no meaning, no soul. It is a piece of commercially safe, made by/for whites, fake "black sound" (130-38). "Summertime" signals the global media's project of promoting rigid and normative blocks of identity, of erasing true hybridity, and quashing resistant voices. Jazz is a central language in this work: a bridge, but also a terrain of cultural contestation. ${ }^{27}$ On a deep allegorical level, in contrast to the corruption of the visible signaled by Mobio's fresco, jazz effectuates a reverse migration from the displaced roots of the African Diaspora culture. It is true Black sound/ soul, and the language of resistance, struggling to be heard and valorized, even in Africa. The ill-starred dancer's own hybrid art loses the battle against the global market as he interprets a traditional Senufo epic in a work that combines African dances, ballet, and even breakdancing, only to be reviled by the audience. The Senufo are a rich Ivorian code in the text; their misuse as tourist attractions, their poverty in the marginalized North, their political opposition to HouphouëtBoigny's dictatorial regime, ${ }^{28}$ as well as the reference to their cultural traditions, are all traces of the local in its struggle against global uniformity. This performance stands in stark contrast to the very last scene, where the authorities have offered a free concert to the masses, and successfully peddle local and national patriotism along with commercial pop versions of world music (177-79).

\section{CERTIFICAT DE CONTRÔLE ANTI-SIDA}

Certificat details the systematic destruction of a biracial family. The African father, a political opponent of an unidentified regime, is accused of carrying AIDS and detained in Africa, incommunicado. His French wife and their daughter try to free him; they are subjected to discrimination and violence, and betrayed by the wife's own racist French

27. Zora Neale Hurston wrote of jazz, warriors, and jungles in "How It Feels to Be Colored Me," World Tomorrow 11 (May 1928): 215-16.

28. Georges Coffy, Le soleil des exclus. Côte d'Ivoire. La lutte pour la démocratie. (Paris: La pensée universelle, 1994). On Lauren Gbagbo in Senufo country, see 69-85. 
father; finally they are incarcerated in Europe and commit suicide. Certificat denounces collective psychosis and its collusion with the state and public institutions in response to AIDS in the West and in Africa.

Fear of contamination leads the "modern" Western world to repression and atavism. Science implodes and racial reasoning takes hold as a coalition of scientists pins the origin of the disease on Africa and in particular on alleged sexual practices with the green monkey. Racial hegemony is enshrined in the exoneration of everyone except Africans, not even defended by their own governments (59-67). In the face of virulent racial suspicion and even attacks, Africans in the West hide and deny their identity. Doumbi-Facoly's sardonic pen takes a Fanonian $\operatorname{look}^{29}$ at various practices of surgical modification that amount to mutilation and can end tragically: one man hates his nose, a woman her buttocks. And many try to pass as members of the "higher" echelon in the racial hierarchy, as Black Americans or Caribbeans (70-77), whose position shifts imperceptibly from liberationist to collusionist. In this grinding but quintessentially postcolonial tragedy, the child has to be the narrator, because as a métisse she is a cipher and mediator of racial conflict. The métisse is not merely a critical reflection on the impossibility of colonial rule, as s/he could be in earlier novels, but signals the preposterous nature of racial classifications, an interpellation of normative discourse about race. In Certificat, distancing operates through an Afrocentric dream sequence linked to ancestral, familial, and village soothsaying traditions and a syncretic religious vision that reclaims Egyptian gods, refusing Western readings of African history that have "disappeared" ancient Egypt from the continent.

Doumbi-Facoly's Certificat paints another type of city: a Western location-most probably Paris-ruled by the laws, discrimination, and violence of "good" citizens. In this city, where the doors of justice close in the two women's face, there is a counter-city, made of African and Caribbean community networks that are called to the rescue. These include the slightly dubious but perfectly accurate African diviner, and the mysterious "Tonton," an elusive character in keeping with the detective/mystery aspect of the work, with contacts on both sides of the cultural and power divide. This is the global contemporary city of the West, whose fractured whiteness is constantly challenged and is linked

29. See Frantz Fanon's denunciation of self-hating mechanisms in his 1952 classic, Black Skin, White Masks, trans. Charles Lam Markmann (New York: Grove Press, 1967). 
by myriad threads to the rest of the world. Globalism is an important subtheme of the novel, since the AIDS crisis itself invokes international responses, or the lack thereof. The narrative of loss and destruction is completed when the two women try to escape with Tonton's help, and reach another European country en route to Africa. Their plane is hijacked by Palestinians and, in the ensuing shoot-out, all passengers are grounded; mother and daughter are caught and forcibly returned. In the mode of disaster and the absurd, Doumbi-Facoly has carefully inscribed a global world where all conflicts end up interconnected and cumulatively affect their victims, identified by their special interracial bonds. Space has an important function in this representation: the village of the father, albeit unnamed, remains a locus of desire and hope, while global spaces such as airports and planes are charged with menacing violence. The virtual space of the child's dream sequence and the suspended one of their attempted flight momentarily abolish the spaces of the global order and propose a counter-globality devoid of oppressive systems.

\section{UN/SPEAKING GLOBAL}

In the end, through ambiguous uses of French, the unspeakable surfaces and takes form in the three novels analyzed here, as it does in other works of the 1980s. In Bain, it surfaces through Ranja's death, which remains clouded in mystery: does this death result from a mere conflict of passion, from a sexual insult and breach of propriety? Was it an accident or a suicide? Or was it a sacrificial offering with Ranja as an unknowing scapegoat? Or again, was he assassinated for his political views by his very collaborators? Silence falls on his death, marked by the uncpened, unreturned letters from his wife, while the cameraman attempts to make sense of the deed, the film, and the fragments of Ranja's life. In Les beaux gosses, the unspeakable is linked to the classical Freudian scene-the brutal murder of the father by the (unknowing) son. The son's incestuous leanings toward his mother explode in her barely whispered revelation of the true crime. When Kairuane is gruesomely hacked to pieces by his former acolytes, the membra disjecta of his unformed identity and speech lie in a garbage can near the road. Finally, in Certificat, the unspeakable vibrates in the treason committed by the racist and colonialist father; he falsifies his own daughter's health certificate, leading to her being fired, hounded, and jailed for fleeing the country. The only possible response to such an act 
is the simultaneous suicide of mother and daughter, who, separated by walls, join to nullify speech itself by ending the narrative of betrayal, and voiding the utterance of triumph over their bodies. Violence makes the unspeakable known and denunciatory: the mother cuts her veins, an echo of the accusation of tainted blood against the husband, and the child seeks exile through death to the land of ancestors, an echo of the father's exile in a no man's land. All in all, in these three texts, resistance to the effects of the global world order has been effectuated through overcoming the unspeakable and through the enunciation of violent acts.

Jonathan Ngate has remarked that Paul Bamboté's Princesse Mandapu (1972), a novel that is foundational in its very singularity, belonged "to a small group of literary African Francophone texts that, since the seventies, broadcast their autonomy, if not their independence, towards French literature," through including and excluding African or other partners in the "workings of their discourse." He adds, "it is quite possible that the French language has become, in these texts, the locus of a separation that reveals the other face of the realm, close but distant, and lets other voices be heard." 30

The global world with which contemporary African literature is contending seems to leave a shrinking place for Francophonie. French must share the stage with other non-African languages: as a sacred language, the vector of faith to many millions of Africans, Arabic maintains a special status. As a language perceived, rightly or wrongly, as the vector of economic development, English has been encroaching steadily. ${ }^{31}$ English can signal the nefarious effects of US interests in the African continent, or open forms of oppositional discourse of African diasporic roots and Blackness. That position by itself confers to it a powerful role as linguistic shadow and crossing. The global also means that "African solutions" - a term used by historian Basil Davidson in speaking of ancient Africa-imply the inscription of African partners, African interlocutors, and African intertextuality in works of literature, as Ngate suggested. Further, in a variety of initiatives of the last

30. Jonathan Ngate, "Princesse Mandapu," PNPA, 9.53/54 (September-December 1986): $184-90 ; 186$.

31. On violent conflicts between the Francophone and Anglophone communities in Cameroon: Mongo Beti, "Cameroun. La deuxième guerre civile a-t-elle commencé?" PNPA 8/48 (November-December 1985): 1-6, and, in the same volume, "Lettre ouverte à tous les parents Anglophones," which is signed, simply, "Étudiants anglophones": 720. 
few decades, texts in African languages have been published. ${ }^{32}$ Some of the very same African authors who write in French, like Michèle Rakotoson, are writing and have been writing, in their own African language/s. Other writers implode the purity of French through the use of moussa. ${ }^{33}$ Others again, like Doumbi-Facoly, ${ }^{34}$ inveigh virulently against Francophonie while writing in French. All of this bodes ill for Francophone exclusivity, and even more so, for the ideological hegemony of Francophonie.

Witness to that opposition is the journal founded by Mongo Beti, entitled Peuples noirs, peuples africains, which, from 1985 to 1991, published a series of vitriolic essays against the role of France in Africa and the function of Francophonie. These were mostly penned by Mongo Beti and Guy Ossito Midiohouan, with such titles as "Le degré zéro de la décolonisation," "Tiens! Revoilà les tirailleurs sénégalais," "Seigneur, délivre-nous de la francophonie," and "Un sottisier francophone." 35 All of this was written in French, an indication of how wide the gulf is between the linguistic use of French and the political content of Francophonie as an institution.

Yet, the sheer volume of literary works being produced in French from outside the Hexagon clearly indicates that Francophone writing is not about to disappear, even if the relationship with the font of that language, France, remains volatile. And regardless of the bitter criticism of France and its role, the leaden weight of US power in matters of international affairs and global economy ${ }^{36}$ engenders other forms of opposition, as virulent or moreso. In the vortex created by resistance to the role of the United States, especially in the first decade of the twentyfirst century, and especially in relation to the exploding Middle East,

32. Pierre Medehouegnon, "Lò ou l'offensive africaine contre la francophonie?" PNPA 8/45 (September-October 1985): 120-22 [collection of proverbs in Fon].

33. See Koffi Kwahulé, Pour une critique du théâtre ivoirien (Paris: L'Harmattan, 1996), 208-10. Moussa is a form of phonetic and broken-down French spoken by Africans in subaltern positions under the French colonial administration and seen by the French as a mark of ridicule, but turned around by African Francophone writers as an implicit resistance to the French language and the politics of linguistic "purity."

34. Doumbi-Facoly, Guide, 30-34; 138-39; 196-97.

35. See Guy Ossito Midiohouan, Mongo Beti, and Max Liniger-Goumaz, "Deux ou trois choses sur 'Jeune Afrique,'" PNPA 8/44 (March-April 1985): 11-34. See, in the same volume, Beti, "Conseils à un jeune écrivain francophone": 52-60.

36. See Denis Bra Kanon (Minister of Agriculture of the Ivory Coast), "Matières premières. Oui au libéralisme, non à l'injustice," Géopolitique africaine (June 1986): 2126. 
there is still a great margin of maneuver for the concept of Francophonie. Globalization is also marked by below-surface tensions among local and regional language, even in Europe, demanding their due, and underscoring the fragility of the artificial power of both English and French.

In sum, the study of African Francophone literature has been, for too long, streamlined into Western and conservative canons and expectations. As Guy Midiohouan suggested, not reading beyond the $1960 \mathrm{~s}$ produces a skewed, ideologically safe perception of this literature. The last two decades in particular have produced a wealth of works that are at once intricate and at times revolutionary, examples of the writer's craft, and complex sites of multiple contestations, rejecting a global world order deleterious to Africans. Within this moment, the writing of the 1980s is crucial to the genealogy of denunciatory African Francophone literature, and the three novels discussed here are highly representative of these currents. All three writers deftly wove the numerous social, cultural, and political conflicts in their country or region into the denunciatory strategies of the novel: for Rakotoson, it was the massive poverty, glorious historical past, colonial and internal political violence of Madagascar. Narrative riddles remain unsolved, and a character marked by sexual and gender ambiguity, the cameraman, must see in lieu of Ranja and complete the filming in the midst of a pageantry of political recuperation. Karoné evoked the violence and deprivation of sprawling modern West African cities, palimpsests of similar conditions in the West, and in particular the powerful USA, thus exposing the latter's fragility along with African realities that include questioning current national/nationalist parameters. Thus, the final celebration of state power run by a multicultural group of exploiters was spoiled by the preceding portrayal of a grieving Julie, having buried the men in her life, slowly proceeding to create her own life ambitus: self-loving gestures, light and bright colors, song, renewed maternity. Doumbi-Facoly took Western nations, represented by France, and despotic African regimes to the mat for their ferocious reactions to and political manipulations of HIV-AIDS. He also conferred the last words of resistance on a trio of women-the grandmother informs the absent "Monsieur le Président" that both her daughter and grand-daughter took their own lives-who refuse silence and oppression through suicide and the maternal genealogy.

In the end, all three novels denounced a wide range of social and po- 
litical ills, and resisted their own pessimistic conclusions in scenes that appear to reiterate the power of hegemonic forces, as they undermine it through characters who occupied marginalized and/or subjected positions. Through a dis/embodied poetics of violence, these novels have shattered the consensual foundations of the global, wielding the trenchant weapon of the disenfranchised, the subaltern, the "peripheral," dissent that can return the "unspeakable" to speech and finally to writing. ${ }^{37}$

37. The most apt metaphor for this process can be found in Karonés last pages: "Forgotten jazz woman who errs among the graves . . torrid shadow chased by a spear of light, Julie Madola eats earth every time. And contrary to popular belief, the earth of the dead has a slight taste of freedom..." (175). 